\title{
Conservation of crop genetic resources in Brazil in the context of the target 9 of the Global Strategy for Plant Conservation
}

\author{
Juliano Gomes Pádua ${ }^{1,2}$
}

\begin{abstract}
Cultivated species, on which humankind depends for survival, have been created by farmers that have crossed and selected wild plants and developed landraces. Early in $20^{\text {th }}$ century, the theory of Centers of Origin of Cultivated Plants was proposed by Vavilov. He also warned the world about the loss of plant genetic diversity due to the dominance of a small number of genetically similar crops, a fact that help starting a movement for the conservation of plant genetic resources. From this time, several strategies and institutions were established around the world to act in plant genetic resources (PGR) conservation. In Brazil, a remarkable player in PGR conservation, some institutions conserve several crop species as well as their wild relatives and other socioeconomically valuable plant species. In this paper we present the status of PGR conservation in Brazil as well as initiatives and laws aiming at respecting, preserving and maintaining associated indigenous and local knowledge, in the context of the target 9 of the Global Strategy for Plant Conservation.

Key words: crop conservation, GSPC target 9, indigenous and local knowledge.

Resumo

Espécies cultivadas, das quais a humanidade depende para sobreviver, foram criadas por agricultores que cruzaram e selecionaram plantas silvestres e desenvolveram variedades. No início do século XX, a teoria dos Centros de Origem dos Plantas Cultivadas foi proposta por Vavilov. Ele também alertou o mundo sobre a perda da diversidade genética de plantas devido ao predomínio de um pequeno número de culturas geneticamente semelhantes, o que ajuda a iniciar um movimento de conservação de recursos genéticos de plantas. A partir deste momento, várias instituições e estratégias foram estabelecidas em todo o mundo para atuar na conservação de recursos genéticos vegetais (RGV). No Brasil, um país com destacada atuação na conservação de RGV, algumas instituições conservam várias espécies de plantas cultivadas, bem como seus parentes silvestres e outras espécies de plantas com valor socioeconômico. Neste artigo, apresentamos o status da conservação de RGV no Brasil, bem como iniciativas e leis destinadas a respeitar, preservar e manter o conhecimento tradicional associado no contexto da meta 9 da Estratégia Global para a Conservação de Plantas. Palavras-chave: conservação de recursos genéticos, meta 9 da GSPC, conhecimento tradicional indígena e local.
\end{abstract}

\section{Introduction}

The genetic diversity of crops and their wild relatives is known as plant genetic resources (PGR). This diversity emerged in interactive and dynamic scenarios where humans, nature, climate and agricultural practices played important roles. PGR provide the biological basis of agricultural production and world food security. They also meet human needs for food, fiber, shelter, and medicines, and contribute to trade and cultural tradition (Borromeo 2012). As the raw material for developing new cultivars, PGR are an insurance for agriculture to overcome future challenges, such as climate and other environmental changes and increasing food demands.

Cultivated species, on which humankind depends for survival, have long been developed by mankind, and in generally, cannot survive without management or cultivation. For millennia, farmers have crossed and selected wild plants, developing landraces, which are dynamic population(s) of a cultivated plant that has historical origin, distinct

\footnotetext{
'Embrapa Recursos Genéticos e Biotecnologia, PqEB, Av. W5 Norte (final), 70770-917, Brasília, DF, Brazil.

${ }^{2}$ Author for correspondence: juliano.padua@embrapa.br
} 
identity and lacks formal crop improvement, as well as often being genetically diverse, locally adapted and associated with traditional farming systems (Camacho Villa 2005).

Maintaining intraspecific genetic diversity, i.e., genetic diversity within species, is essential for developing new varieties that will be able to maintain yield stability and to adapt to new diseases and other environmental challenges, mainly those resulted from climate change (Atlin et al. 2017). The further development of agriculture, and the world's food security, will depend on farmers and breeders continuing to have access to the plant genetic resources and its associated information. Despite the importance of PGR, The Food and Agriculture Organization of the United Nations (FAO) estimates that about $75 \%$ of the genetic diversity of agricultural crops has been lost in the last century, due to the widespread abandonment of genetically diverse traditional crops in favor of genetically uniform modern crop varieties (FAO 200--?).

In the $20^{\text {th }}$ century, the rise of genetic and plant breeding sciences, popularized the concepts of natural selection established by Darwin and the genetic laws, discovered by Mendel, and consequently, they contributed to the theories of plant genetic variability. At that time, humans discovered the importance of genetic variation to plant breeding, and for that reason some countries started to collect plant germplasm aiming at establishing genetic banks. During 1920s and 1930s, the russian Vavilov proposed the theory of Centers of Origin of Cultivated Plants, represented by eight areas of the world classified as the origins of food crops. He also warned the world about the loss of plant genetic diversity due to the dominance of a small number of genetically similar crops, a fact that helped boosting a movement for the conservation of plant genetic resources (Harris 1990). Vavilov's work inspired botanists, plant breeders, and explorers in the second half of the twentieth century, including Jack Harlan, Erna Bennett, John Hawkes, and Otto Frankel which culminated into a global movement for conservation of plant genetic resources, (Pistorius 2007).

In 1960s, the Food and Agricultural Organization (FAO), an agency of the United Nations Organization (ONU), became concerned about the loss of plant genetic diversity of wild and domesticated relatives of food crops (Baranski 2013). In 1967, both FAO and the
International Biological Program (IBP), organized the "Technical Conference on the Exploration, Utilization and Conservation of Plant Genetic Resources", held in Rome, where the term "genetic resources" was coined. The scientists Erna Bennett and Otto Frankel, argued about the strategies to safeguard plant genetic resources, if in the field through farmers' participation, as Bennet stated, or using the seed banking approach, according to Frankel. Currently, it is clear that an efficient conservation program must use both in situ and $e x$ situ approaches. On-farm and in situ conservation and management of plant genetic diversity complements ex situ conservation (Maxted et al. 1997). In addition, in situ conservation allows the continued evolution of plant diversity to adapt to changing environments (Vigouroux et al. 2011) and conserving a wider genetic base (Scarcelli et al. 2006).

In 1971, the Consultative Group for International Agricultural Research (CGIAR), directed by the World Bank (Baranski 2013) was created. CGIAR acts by integrating conservation of plant genetic resources and their use in agricultural research and plant breeding. The FAO Commission on Genetic Resources for Food and Agriculture was established in 1983 (Sullivan 2004). The Commission guided FAO in the first assessment of the State of the World's Plant Genetic Resources for Food and Agriculture, published in 1996. This Commission led negotiations that culminated in 1996, when 150 countries adopted the Global Plan of Action for the Conservation and Sustainable Utilization of Plant Genetic Resources for Food and Agriculture (FAO 2012).

In 1989, the Commission on Genetic Resources for Food and Agriculture called for the establishment of networks of in situ conservation areas for PGRFA, for both crops and their wild relatives (Maxted \& Kell 2009). The Global Plan of Action for the Conservation and Sustainable Utilization of Plant Genetic Resources for Food and Agriculture (FAO 2012) includes conservation of crop wild relatives (CWR) as a priority area, and The International Treaty on Plant Genetic Resources for Food and Agriculture (ITPGRFA), in its article 5 (FAO 2009), promotes the in situ conservation of CWR.

In 2002, The Crop Trust was established by Bioversity International, the new name of IPGRI - International Plant Genetic Resources Institute, on behalf of the CGIAR and the UN Food and Agriculture Organization, to help support this 
global system. It also provides long-term grants to safeguard collections of unique and valuable crop diversity held in genebanks around the world. Priority was given to 25 crops among those listed in Annex 1 of the International Treaty (FAO 2009), due to the particular importance for food security of least developed countries.

In 2008, the Global Svalbard Seed Vault was opened launched with the objective to "provide a safety net for the international conservation system of plant genetic resources, and to contribute to the securing of the maximum amount of plant genetic diversity of importance to humanity for the long term in accordance with the latest scientific knowledge and most appropriate techniques" (NMAF 2017). It is managed under terms spelled out in a tripartite agreement between the Norwegian government, the Crop Trust and the Nordic Genetic Resource Center - NordGen (Westengen et al. 2013).

In 2010, FAO published the Second Report of the State of the World's Plant Genetic Resources for Food and Agriculture (FAO 2010). Between the two reports, the total number of accessions conserved ex situ worldwide has increased by approximately 20 percent, the number of accessions of minor crops and CWR are still underrepresented and the scientific understanding of the on-farm management of genetic diversity has increased (FAO 2010).

The threat to species and ecosystems and also the importance of genetic resources, led the United Nations Environment Program (UNEP) to call for an international Convention on Biological Diversity. The Convention was opened for signature in 1992 at the United Nations Conference on Environment and Development (the Rio "Earth Summit"). It states that signatory countries should: 1) regulate or manage biological resources important for the conservation of biological diversity whether within or outside protected areas, with a view to ensuring their conservation and sustainable use [Article 8 (c)]; and 2 ) respect, preserve and maintain knowledge, innovations and practices of indigenous and local communities embodying traditional lifestyles relevant for the conservation and sustainable use of biological diversity and promote their wider application [Article 8 (j)] (Convention on Biological Diversity 1992).

The International Treaty on Plant Genetic Resources for Food and Agriculture (ITPGRFA), in harmony with the CBD, provides for the conservation and sustainable use of plant genetic resources for food and agriculture, as the basis for sustainable agriculture and food security. It was adopted by the Thirty-first session of the FAO Conference on November $3^{\text {rd }}, 2001$ (FAO 2009).

The ITPGRFA(Articles 10-12) places 36 crop species and 29 genera of forages in a multilateral system and guarantee access to these resources for breeding and research (FAO 2009). Germplasm from the multilateral system will be available under Standard Material Transfer Agreements (SMTA) that may include provisions for benefit-sharing in the event of commercialization. The ITPGRFA also provides for Farmers' Rights. Currently, more than 50 countries are developing ABS or ABS-like policies.

A group of botanists (the Gran Canaria Group) took the idea of a global plant conservation program and developed the Global Strategy for Plant Conservation (GSPC). During the COP 6 , in 2002, the GSPC was adopted. Parties and Governments were further invited to develop national and/or regional targets and to incorporate these into relevant plans, programs and initiatives. Among several targets presented by GSPC, Target 9 is specific to crops, and calls for at least 70 per cent of the genetic diversity of crops and other major socio-economically valuable plant species to be conserved, and associated indigenous and local knowledge have to be maintained.

\section{Material and Methods}

The majority of genebanks in Brazil is not well documented and consequently information is not easy available, as observed in several countries. Despite of having a well organized curatorship system, Embrapa developed an institutional documentation and informatization system (Alelo) only in 2013.

Thus, we got the information to have an overview of the status of plant genetic resources conservation in Brazil directly from the curators of different institutions. Other source of information were: (i) Alelo, the Embrapa's database related to genetic resources; (ii) the Second Report on the State of the World's Plant Genetic Resources for Food and Agriculture and (iii) the literature available that presents records on the status of genebank and collections of plant genetic resources.

National and State Laws and Decrees which deal with preserving and maintaining associated indigenous and local knowledge are presented. 


\section{Results and Discussion}

Plant genetic resources conservation

Over the last years, Brazil has made significant progress in conservation and use of plant genetic resources. Regarding in situ conservation, important progress has been made due to the creation of several conservation units. Furthermore, other important government initiatives have arisen from the ratification by Brazil of the Convention on Biological Diversity in 1994. The National System of Conservation Units has been implemented, and for that, Brazil currently has one of the most remarkable systems of protected areas in the world. Strategies for onfarm management have been established by the Brazilian government with the goal of ensuring historic-cultural conservation of food plant species and varieties used by traditional farmers. Strategies adopted for on-farm conservation in Brazil comprise participatory breeding, seed fairs, local seed banks and agrobiodiversity dissemination centers.

In the $1970 \mathrm{~s}$, FAO encouraged the establishment of a global network of Centres for the Conservation of Genetic Resources, in the regions with the highest genetic variability in the world. In 1974, the International Board for Plant Genetic Resources (today, Bioversity International), was created by CGIAR. In this same year, EMBRAPA established a research unit whose mission is to coordinate the activities of genetic resources management. This Unit was named the National Centre for Genetic Resources (CENARGEN), today Embrapa Genetic Resources and Biotechnology.

Before the establishment of CENARGEN, activities related to genetic resources were, with a few exceptions, conducted only in a casual and sporadic way in Brazil. According to Mariante et al. (2009), some institutions pioneered the establishment and conservation of plant collections in Brazil, as the Instituto Agronômico de Campinas (IAC), the Instituto do Açúcar e do Álcool - IAA and the Cooperativa dos Produtores de Cana-deAçúcar (COPERSUCAR); the Comissão Executiva de Planejamento da Lavoura Cacaueira (CEPLAC); the Escola Superior de Agricultura "Luiz de Queiroz" (ESALQ/USP) and Universidade Federal de Viçosa (UFV). With the creation of Embrapa Genetic Resources and Biotechnology and the consolidation of the National Agricultural Research System (SNPA), a positive environment was put in place, favoring the establishment of a national genetic resources network that includes universities and agricultural research institutions.

With the participation of different institutions, the Portfolio of Strategic Management of Genetic Resources for Food, Agriculture and Bioindustry currently maintains 98 Active Plant Germplasm Banks, including those that belong to Embrapa and to SNPA institutions.

An updated inventory of this system (Azevedo and Bustamante 2014) pointed out that there are in Brazil over 250,000 plant germplasm accessions, including duplicates, of which about 110,000 are stored in long-term conditions at Embrapa's Base Collection (COLBASE). Other 1,500 accessions which belong to species that produce non-orthodox seeds or that are vegetatively propagated or present high degree of heterozygosity are conserved using in vitro conditions. The IAC conserves species related to agriculture in 14 remarkable collections: fibrous species, oleaginous, cereal and beans, roots and tubers, stimulating plants, sugarcane, fruits, citrus, legumes, maize and sorghum, medicinal and aromatics, rubber, Zingiberales, and Arecaceae (São Paulo 2017).

Several institutions in Brazil conserve small collections of plant species interesting for food and agriculture, but they are not quantified and data are not available. Most of these collections do not have preservation purposes, but they are collections to attend specific research demands. In the last years, Embrapa developed a system, named Alelo, accessible at $<\mathrm{http}$ ://alelo.cenargen. embrapa.br>, to document collections of genetic resources. It is expected that, in the long-term, after several institutions will be using Alelo, a more realistic assessment of plant genetic conservation in Brazil could be done. Table 1 presents the status of conservation of the main crops cultivated in Brazil. The number of accessions is a rough approximation due to lack of updated information.

There is a large number of collections which conserve minor crops, or socio-economically valuable plant species: assai palm (Euterpe Mart.), peach palm (Bactris Jacq. ex Scop.), forages (Urochloa P. Beauv., Pennisetum Rich., Paspalum L., Stylosanthes Sw. and other genera), several fruit species as Acerola (Malpighia Juss.), Apple (Malus Mill.), Avocado (Persea Mill.), Guava (Psidium L.), Cashew (Anacardium L.), Coconut (Cocos L.), Cupuassu (Theobroma L.), Grapes (Vitis L.), Mangaba (Hancornia Gomes), Mango (Mangifera L.), Papaya (Carica L.), Passionfruit (Passiflora 
Table 1 - Number of accessions conserved around the world and in Brazil of the main crops cultivated in Brazil.

\begin{tabular}{lccc}
\hline Crop & $\begin{array}{c}\text { Accessions conserved } \\
\text { worldwide }\end{array}$ & \multicolumn{2}{c}{ Accessions conserved in Brazil } \\
\cline { 2 - 3 } Banana & 13,000 & Reference \\
Cocoa & 24,370 & 383 & Alelo, CR \\
Cassava & $+32,000$ & 4,000 & Cacaonet \\
Citrus & 30,000 & 4,378 & Alelo, CR \\
Coffee & 30,307 & 2,134 & Invent, CR \\
Common bean & 262,000 & 5,839 & Invent, CR \\
Cotton & 104,708 & 16,590 & Alelo, CR \\
Groundnut & 128,461 & 4,500 & CR \\
Maize & 327,932 & 4,532 & CR \\
Oilpalm & 21,103 & 6,579 & CR \\
Potato & 98,000 & 564 & Alelo \\
Rice & 775,000 & 410 & Alelo, CR \\
Sorghum & $+235,000$ & 28,754 & Invent, CR \\
Soybean & 230,000 & 7,795 & CR \\
Sugarcane & 41,000 & 18,126 & Invent, CR \\
Wheat & 856,168 & 5,000 & CR \\
\hline
\end{tabular}

Source: The Second Report on the State of the World's Plant Genetic Resources for Food and Agriculture. (Alelo $=<$ http://alelo.cenargen.embrapa.br $>$; Invent $=$

Inventory of genetic resources at Embrapa (Azevedo \& Bustamante 2014); CR = Brazil's country report (Mariante et al. 2009); Cacaonet $=<$ http://www.cacaonet.org/ $>$ ).

L.), Pineapple (Ananas Mill.), Peach (Prunus L.), Umbu (Spondias L.) and others of regional importance. Important collections of vegetables are conserved: Pepper (Piper L. and Capsicum L.), Cucumber (Cucumis L.), Pumpkins (Cucurbita L.), Lima beans (Phaseolus lunatus L.), Melon (Cucumis melo L.), Onion (Allium L.), Tomato (Solanum L.) and non-conventional vegetables in the genera Pereskia Mill., Dioscorea L., Basella L., Anredera Juss., Pachyrhizus Lindl., Cyclanthera A. Juss., Maranta Plum. ex L., Colocasia Schott, Xanthosoma Schott, Hibiscus L., Cichorium L., Rumex L., Amaranthus L., Eryngium L., Spilanthes Jacq., Stachys L., Sonchus L., Erechtites Raf. and Talinum Adans.

Nevertheless, some species are underrepresented in collections, mainly crop wild relatives. In Brazil, two good examples are: Manihot spp. Mill. and Gossypium spp. L., the genera of cassava and cotton, respectively. Barroso et al. (2010) presented a dramatic status of Gossypium mustelinum Miers, a native species from Northeastern Brazil which belongs to the primary gene pool of the cultivated cotton. Populations of this species became extinct in Caicó, Rio Grande do Norte. Only eleven individuals were found in a unique population. In Jaguarari, one population became extinct, but a new one was found with approximately 500 individuals. The population from Macururé consists of only 28 individuals.

Nassar (2006) reports that in 2001, at least 18 Manihot taxa were no longer found at locations originally recorded in the 1960 s and 70 s. Three microcenters of diversity (Chapada dos Veadeiros, Corumbá de Goiás, Pirenópolis and Goiás Velho) are under threat due to unsustainable tourism (Nassar 2006). In Brazil there are several community seed banks that conserve several species. They are local-level organizations that contribute to seed conservation, mainly of farmer varieties. The legal framework to support community seed banks comprises national and states law. Three Brazilian States (Alagoas, Minas Gerais and Paraíba) approved laws to provide a legal framework for community seed banks. These laws aimed at strengthening seed banks by stimulating (i) recovery and conservation of species and varieties cultivated by family-farmers; (ii) protection of local genetic resources; (iii) to protect agrobiodiversity, traditional knowledge 
and cultural values associated, and (iv) capacity building for seed bank management. At the national level, several articles in law 13.123 (Brasil 2015) promote on-farm conservation and states about benefit-sharing, as discussed below. In the last years, the Federal Government has invested in the construction of hundreds of creole seed banks (Brasil 2017).

Respecting, preserving and maintaining associated indigenous and local knowledge

The Policy for the Sustainable Development of Traditional Peoples and Communities (PNPCT), established in 2007 by the Decree 6040 (Brasil 2007), is an action of the Federal Government that seeks to promote the sustainable development of traditional people and communities. According to this same decree, Traditional Peoples and Communities are groups differentiated culturally and who recognize themselves as such, who have their own forms of social organization, occupy and use territories and natural resources as a condition for their cultural, social, religious, ancestral and economic continuity, using knowledge, innovations and practices generated and transmitted by tradition (Brasil 2007). This policy emphasizes the recognition, strengthening and securing of their land, and their social, environmental, economic and cultural rights. It further contributes to the respect and value of the identity, forms of organization and institutions of traditional people and communities. The National Commission for Sustainable Development of Traditional Peoples and Communities, that is responsible to coordinate the implementation of this policy, is composed of fifteen representatives of the agencies and entities of the federal public administration and fifteen representatives of non-governmental organizations.

Another initiative of great relevance was the recognition by the Institute of National Historical and Artistic Heritage (IPHAN) of the Traditional Agricultural System of the Rio Negro as an Intangible Cultural Heritage of Brazil (Brasil 2018). The recognition was formalized in December 2010. The construction process of the safeguarding plan for this agricultural system - that has cassava cultivation as a structural element and includes 23 indigenous ethnic groups - considered the practices and principles of traditional populations for conservation of agro-biodiversity.

The National Policy of Agro-ecology and Organic Production, which was built in conjunction with the civil society, was launched on August 20, 2012 through Decree No. 7794 (Brasil 2012). Among others aspects, the policy aims the enhancement of agricultural biodiversity and sociobiodiversity products. Furthermore, its objective is to encourage the local experiences of use and conservation of plant and animal genetic resources, especially those that involve the management of local, traditional or landraces breeds and varieties. Moreover, it aims to contribute for reducing gender inequalities through actions and programs that promote the economic women empowerment.

Brazil is not only a biologically diverse country. Its ethnic richness is large. There are more than 230 indigenous peoples living in the country and speaking 180 different languages. Of these 230 peoples, more than 210 inhabit the Brazilian Amazon, which correspond to almost half of the 446 recognized indigenous people living in the whole-Amazon basin by various countries that comprise it (Brand \& Calderoni 2012).

Brazil published the law 13.123 of May $20^{\text {th }} 2015$ (Brasil 2015) that regulates access to genetic heritage, on the protection and access to associated traditional knowledge and the benefit sharing for conservation and sustainable use of biodiversity. The law empowered the Genetic Heritage Management Council - CGen as the Brazilian Access and Benefit-sharing (ABS) National Competent Authority. The CGen consists of representatives from bodies and entities of the federal public administration that are competent on the various actions of this law and the representation of civil society. There are 11 Ministries and nine representatives of civil society, three of each of the following sectors: (i) Business Sector, (ii) Academia and (iii) Indigenous people, traditional communities and traditional farmers.

Concerning to ABS, the new law brought a secure scenario for users of genetic resources and biodiversity, since clear rules for benefit sharing were established. ABS could be implemented through monetary ( $1 \%$ of annual net revenue or up to $0.1 \%$ by sectorial agreement) or by non-monetary mechanisms, like (i) projects for conservation, sustainable use of biodiversity, protection and maintenance of knowledge, innovations and practices of populations holders of traditional knowledge; (ii) technology transfer; (iii) training of human resources on issues related to conservation and sustainable use of genetic heritage or associated traditional knowledge, or (iv) free distribution of products in programs of social interest. 
If the provider of the genetic material can be identified, the law determines that the beneficiary of ABS must be the provider, which can be indigenous people, traditional communities or traditional farmers. Otherwise, if it is not possible to identify the provider, the beneficiary is the Government, represented by the Ministry of the Environment, and the payments must be done to the national fund for benefit sharing - FNRB. This Fund will be employed to create, recover or maintain ex situ collections, if they were the providers and also it will be used exclusively for the benefit of traditional knowledge holders. The fund seek to promote: (i) conservation of biological diversity; (ii) survey and inventory of genetic resources; (iii) training of human resources associated with the use and conservation of genetic heritage and associated traditional knowledge; (iv) promotion of research and technological development associated with genetic heritage and associated traditional knowledge.

\section{Gaps and needs to be stressed} after 2020

Despite Brazil plays a remarkable role on conservation of agrobiodiversity, the collections of plant genetic resources, both in situ/on farm and ex situ, present gaps and needs. Crop wild relatives receive little or no attention concerning conservation issues. In situ conservation of wild species of agricultural importance occurs mainly as an unplanned result of efforts to protect particular habitats or charismatic species (Maxted 2009). Thus, floristic inventories in conservation units must be conducted to clarify this aspect. In the case of on-farm conservation, in general, CWR do not present value to direct cultivation and farmers consider them as undesirable plants. In genebanks, CWR are underrepresented. Then, actions to promote an integrative approach between in situ and ex situ strategies must be implemented to conserve crop wild relatives.

It is necessary to strengthen the ability of farmers, indigenous and other stakeholders, to sustainably conserve and manage agrobiodiversity. Scientific recommendation could led to some improvements on on-farm conservation practices and mitigate genetic erosion.

It will be important to establish a national coordination and collaboration among national government institutions, especially between the agriculture and environment sectors. This framework must also involve non-government organizations associated to farmers and indigenous people. In this arrangement, in situ and ex situ conservation strategies need to be better linked to ensure that a maximum amount of genetic diversity is conserved as well as cultural information.

Strengthened research capacity is required in many areas related to conservation and sustainable use of plant genetic resources. To establish an efficient conservation program, it is necessary to characterize species according to its seed storage behavior aiming at identify the right conservation method to each species. To develop efficient protocols to seed germination and methods to overcome seed dormancy are imperative. Sampling strategies must be well designed to capture a representative amount of genetic variation. It is necessary to evaluate how well the methods for collecting, preserving and distributing the genetic material were designed (Hernandez-Suarez 2018).

Reduced funds, human capacity and facilities to conduct the main activities related to conservation of plant genetic resources like collecting, conserving, regenerating, characterizing, documenting and distributing is a common place. To establish a mechanism to support in situ and ex situ actions is imperative. While seed collections are larger and more secure, the situation is critical in the case of vegetative propagated species and species whose seeds cannot be dried and stored at low temperatures.

As presented, Brazil has implemented over the last few years several actions related to the conservation of genetic resources of plants and to the associated traditional knowledge. Regarding the preservation and maintenance of traditional knowledge associated with genetic resources, the new Brazilian legislation has brought significant advances, as discussed previously.

Some gaps still need to be filled with regarding to the conservation of wild relatives, combining actions involving in situ, ex situ and on-farm conservation. Efforts for the conservation of native species of the genus Manihot Mill., Passiflora L. and Gossypium L., for example, should be implemented. The same attention should be given to species of regional importance, such as the native species from Amazonia and Cerrado.

Quantifying how much of the genetic diversity of cultivated plants, their wild relatives and other socio-economically valuable plants is currently conserved is not an easy task. Thus, it is not possible to quantitatively evaluate whether 
Brazil will be able to meet the established goal of conserving $70 \%$ of the diversity of these plants by 2,020 .

However, according to the FAO report on the conservation of plant genetic resources, Brazil is one of the largest holders of collections of cultivated plants and wild relatives in the world (FAO 2010). For sure, there are wild relatives of the cultivated species inside conservation units in Brazil. Floristic studies are needed to determine which of these species are present in these areas.

Considering the above statements, it is assumed that the goal established for the conservation of $70 \%$ of the genetic diversity of cultivated plants and their wild relatives and other plants of socio-economic value can be met by 2,020 .

Despite this imprecision, it is recommended that this goal be maintained for the period $2,020-2,030$ and that floristic inventories in conservation units must be encouraged. Efforts must be concentrated to foster studies about the genetic diversity conserved in ex situ collections and by indigenous communities and traditional farmers. The results of these researches will clarify the question about how much of the plant genetic diversity is conserved, allowing the establishment of efficient public policies in Brazil.

\section{Acknowledgements}

The author deeply acknowledge Embrapa.

\section{References}

Altieri MA \& Merrick LC (1987) In Situ conservation of crop genetic resources through maintenance of traditional farming systems. Economic Botany 41: 86-96.

Atlin GN, Cairns JE \& Das B (2017) Rapid breeding and varietal replacement are critical to adaptation of cropping systems in the developing world to climate change. Global Food Security 12: 31-37.

Azevedo VCR \& Bustamante PG (2014) Recursos genéticos de plantas conservados na Embrapa: histórico e inventário atualizado. Embrapa, Brasília. 184p.

Baranski M (2013) Seed collection and plant genetic diversity, 1900-1979. Embryo Project Encyclopedia. ISSN: 1940-5030. Available at $<$ http://embryo.asu.edu/ handle/10776/6468>. Access on 05 December 2017.

Barroso PAV, Hoffmann LV, Freitas RB, Batista CEA, Alves MF, Silva UC \& Andrade FP (2010) In situ conservation and genetic diversity of three populations of Gossypium mustelinum Miers ex Watt. Genetic Resources and Crop Evolution 57: 343-349.
Bellon MR, Dulloo E, Sardos J, Thormann I \& Burdon JJ (2017) In situ conservation - harnessing natural and human - derived evolutionary forces to ensure future crop adaptation. Evolutionary Applications 10: $965-977$.

Borromeo TH (2012) Importance of plant genetic resources in sustainable development: global challenges, and solutions being developed in the Philippines. Journal of Developments in Sustainable Agriculture 7: 23-32.

Brand AJ \& Calderoni VAMO (2012) Povos indígenas e formação acadêmica: ambivalências e desafios. Currículo sem Fronteiras 12: 85-97.

Brasil (2007) Decreto ${ }^{\circ}$ 6.040, de 7 de fevereiro de 2007. Institui a Política Nacional de Desenvolvimento Sustentável dos Povos e Comunidades Tradicionais. Diário Oficial da República Federativa do Brasil, Brasília, DF. 8 de fevereiro de 2007. Pp. 316.

Brasil (2010) Ministério da Cultura. Instituto do Patrimônio Histórico e Artístico Nacional (IPHAN). Sistema Agrícola Tradicional do Rio Negro. Available at $<$ http://portal.iphan.gov.br/pagina/ detalhes/75>. Access on 08 January 2018.

Brasil (2012) Decreto $n^{\circ} 7.794$, de 20 de agosto de 2012. Institui a Política Nacional de Agroecologia e Produção Orgânica. Diário Oficial da República Federativa do Brasil, Brasília, DF. 21 de agosto de 2012. Seção 1. Pp. 4.

Brasil (2015) Lei $\mathrm{n}^{\circ} 13.123$ de 20 de maio de 2015. Regulamenta o inciso II do $\S 1^{\circ}$ e o $\S 4^{\circ}$ do art. 225 da Constituição Federal, o Artigo 1, a alínea j do Artigo 8, a alínea c do Artigo 10, o Artigo 15 e os $\S \S 3^{\circ}$ e $4^{\circ}$ do Artigo 16 da Convenção sobre Diversidade Biológica, promulgada pelo Decreto no 2.519 , de 16 de março de 1998; dispõe sobre o acesso ao patrimônio genético, sobre a proteção e o acesso ao conhecimento tradicional associado e sobre a repartição de benefícios para conservação e uso sustentável da biodiversidade; revoga a Medida Provisória no 2.186-16, de 23 de agosto de 2001; e dá outras providências. Diário Oficial da República Federativa do Brasil, Brasília, DF. 14 maio de 2015.

Brasil (2015) Ministério do Desenvolvimento Social. MDS investe na construção de 600 bancos de sementes crioulas. Available at $<$ http://www.brasil. gov.br/cidadania-e-justica/2015/01/mds-investe-naconstrucao-de-600-bancos-de-sementes-crioulas $>$. Access on 01 December 2017.

Convention on Biological Diversity (1992) Nairobi. United Nations Environmental Program. United Nations, Nairobi. 28p.

Camacho Villa TC, Maxted N, Scholten MA \& FordLloyd BV (2005) Defining and identifying crop landraces. Plant genetic resources: characterization and utilization 3: 373-384.

FAO (2009) International treaty on plant genetic resources for food and agriculture. FAO, Roma. 59p. 
FAO (2010) Second report on the state of the world's plant genetic resources for food and agriculture. Commission on Genetic Resources for Food and Agriculture, Roma. 370p.

FAO (2012) Synthetic account of the second global plan of action for plant genetic resources for food and agriculture. FAO, Roma. 20p.

FAO (200--?) What is happening to agrobiodiversity? Available at <http://www.fao.org/docrep/007/ y5609e/y5609e02.htm>. Access on 05 December 2017.

Frankel OH, Brown AHD \& Burdon JJ (1995) The conservation of plant biodiversity. Cambridge University Press, Cambridge. 299p.

Harris DR (1990) Vavilov's concept of centres of origin of cultivated plants: its genesis and its influence on the study of agricultural origins, Biological Journal of the Linnean Society 39: 7-16.

Hernandez-Suarez C (2018) Measuring a representativeness of a germplasm collection. Biodiversity and Conservation 27: 1471-1486.

Mariante AS, Sampaio MJA \& Inglis MCV (2009) The state fo Brazil's plant genetic resources: second national report: conservation and sustainable utilization for food and agriculture. Embrapa Informação Tecnológica, Brasília. 236p.

Maxted N, Ford-Lloyd BV, Hawkes JG (1997) Complementary conservation strategies. In: Maxted N, Ford-Lloyd BV \& Hawkes JG (eds.). Plant genetic conservation: the in situ approach. Chapman and Hall, London. Pp. 15-39.

Maxted N \& Kell S (2009) Establishment of a global network for the in situ conservation of crop wild relatives: status and needs. FAO commission on genetic resources for food and agriculture, Roma. 112p.
Nassar NMA, Hashimoto DYC \& Fernandes SDC (2008) Wild manihot species: botanical aspects, geographic distribution and economic value. Genetics and Molecular Research 7: 16-28.

NMAF (2007) Agreement between the Royal Norwegian Ministry of Agriculture and Food, The Global Crop Diversity Trust and the Nordic Gene bank providing for the funding, management and operation of the Svalbard Global Seed Vault. Available at <http://www.regjeringen.no/en/ dep/lmd/campain/svalbard-global-seed-vault. html?id=462220 $>$. Access on 15 December 2017.

Pistorius R (1997) Scientists, plants and politics - a history of the plant genetic resources movement. International Plant Genetic Resources Institute, Rome. 134p.

SÃO PAULO (2017) Secretaria de agricultura e abastecimento. Agência Paulista de Tecnologia dos Agronegócios (APTA). Available at <http:// www.apta.sp.gov.br/curadoria.php $>$. Access on 01 December 2017.

Vigouroux Y, Barnaud A, Scarcelli N \& Thuillet AC (2011) Biodiversity, evolution and adaptation in cultivated crops. Comptes Rendus Biologies 334: 450-457.

Scarcelli N, Tostain S, Mariac C, Agbangla C, Da O, Berthaud J \& Pham JL (2006) Genetic nature of yams (Dioscorea spp.) domesticated by farmers in W Africa (Benin). Genetic Resources and Crop Evolution 53: 121-130.

Sullivan SN (2004) Plant genetic resources and the law: past, present, and future. Plant Physiology 135: 10-15.

Westengen OT, Jeppson S \& Guarino L (2013) Global ex-situ crop diversity conservation and the svalbard global seed vault: assessing the current status. PLoS ONE 8: e64146. 